\title{
Genetic Diversity of Spatially Isolated Populations of Coconut Caterpillar, Opisina arenosella (Oecophoridae: Lepidoptera)
}

\author{
K. Muralimohan ${ }^{1}$, B. Shivanna ${ }^{1}$ and N. Nagesha ${ }^{2} *$ \\ ${ }^{1}$ Department of Agricultural Entomology, ${ }^{2}$ Department of Plant Biotechnology, \\ College of Agriculture, University of Agricultural Sciences, GKVK, \\ Bangalore 560065, Karnataka, India \\ *Corresponding author
}

\section{A B S T R A C T}

The genetic relationship among 14 spatially segregated populations of Karnataka and one each population from Kerala and Gujarat was established using polymerase chain reaction

Keywords

Opisina arenosella, Genetic diversity, RAPD analysis, Coconut caterpillar spread

Article Info

Accepted:

12 December 2018

Available Online:

10 January 2019 and arbitrary primers. A total of 24 random decamer DNA primers belonging A, B, C, G, $\mathrm{H}$, I and ' $\mathrm{L}$ ' series were used for RAPD-PCR. The lowest genetic similarity was noticed between the farthest populations and highest between the closest populations. Higher similarity index values were found among the populations within Karnataka. Pooled data revealed the lowest genetic similarity index of 0.63 between Kerala and Gujarat populations followed by 0.68 each between Kadur and Gujarat populations. A maximum genetic similarity of 0.98 was recorded among Malpe and Padubidre populations (Mangalore taluk). The overall genetic similarity between populations of $O$. arenosella ranged from 63 to $98 \%$, which may be considered as 'high'. On a broad scale, results obtained agreed with the hypothesis proposed that spatial distance and genetic similarity were inversely related. High genetic similarity between the populations of $O$. arenosella suggests 1) populations arise from a common nucleus population, 2) populations inbreed and 3) immigration/emigration is practically zero. Corroborating with the argument, the polyphagous and migratory species like Helicoverpa armigera is reported to have a higher levels of genetic variability among the populations within and between locations.

\section{Introduction}

An estimation of the magnitude and distribution of genetic variation is crucial for understanding population structures. Elucidation of genetic variation in geographical populations can be an important aspect of pest studies (Kambhapati et al., 1990). Within the native habitat, the extent of genetic variation between geographical populations depends on several factors including gene flow between populations and time since isolation (Hartl, 1980; Templeton et al., 1990).

Various parameters such as morphological characteristics, aggressiveness towards different genotypes, and protein and metabolite profiles are routinely employed to study the population structure of number of 
pests. Data on DNA polymorphisms have been used to describe the genetic variation and population structure of various insect pests (Loxdale et al., 1996).

The Randomly Amplified Polymorphic DNA (RAPD) technique has been widely applied for estimating genetic relationships in several insect species. This technique is used to establish the genetic diversity between and among populations (Cenis, 1993, Haymer, 1994; Apostol et al., 1996; Blok et al., 1997, Silveira et al., 1998). Geographical origin of populations of Litronotus bonariensis, an introduced pasture pest in New Zealand was studied using RAPD markers (Williams et al., 1994). Through RAPD markers the genetic variability within and between geographical populations of Helicoverpa armigera was measured to understand the population structure (Fakrudin et al., 2004).

Coconut caterpillar, Opsina arenosella is a noted serious pest on coconut palms in the entire Indian peninsula and other coconut cultivation regions. This insect species occurs in contiguous specially segregated patches. It is one of the few species among tropical insects to occur in discrete generation cycles (Ramkumar et al., 2006). Hence, at any given point of time all stages of the insect are not noticed in contrast to insect species occurring in continuous generation cycles. Though, sometimes the pest infested coconut patches are close by, the prevailing insect stages in each of these patches would be different, suggesting occurrence of two distinct populations in these patches. Similarly, the populations in far off patches can be seen occurring in same stages of its life cycle. This pattern of distribution opens up an interesting question about spread of infestation from one location to another location. Here, it is hypothesized that a given population $O$. arenosella spreads to nearby coconut patch/s and establishes as a separate population over a period of time. This new population could be asynchronous with the mother population with regards to stages of the insect prevailing in both of these infested patches. If this is true then the genetic variation should be minimum between closely located populations and maximum among the far off populations.

\section{Materials and Methods}

\section{Larvae collection and genomic DNA isolation}

Larvae of Opisina arenosella from 16 spatially isolated populations were collected from the caterpillar infested orchards. Larvae were collected from 14 locations in Karnataka and one location each from Kerala and Gujarat. Location details are provided in table 1.

For the DNA isolation well grown larvae belonging $7^{\text {th }}$ and $8^{\text {th }}$ instars were selected from the field populations. If the larvae were small in their early instars, then they were reared in the laboratory till larvae reached the desired stage. This was followed for all the locations. Selected larvae were anaesthetized using chloroform and dissected to remove digestive system and the fat tissues. DNA was isolated from fifteen larvae collected from each location. Only integument and the head were used for extraction of DNA.

The genome of $O$. arenosella has not been characterized till date. Therefore, in the absence of any specific information on sequence of $O$. arenosella, RAPD-PCR technique was used to measure the genetic diversity among the geographically isolated populations collected from across different regions of Karnataka along with the populations collected from Kerala and Gujarat. The genomic DNA was extracted from the isolated larvae by following CTAB method (Murray and Thompson, 1980) 
followed by purification of the isolated genomic DNA (Maniatis et al., 1982). The genomic DNA isolated was quantified by ethidium bromide fluorescent quantification method (Maniatis et al., 1982). Isolated DNA was run in 0.8 per cent agarose gel electrophoresis (agarose dissolved in $40 \mathrm{ml}$ of 1X TAE buffer containing Ethidium bromide @ $0.5 \mu \mathrm{g} / \mathrm{ml}$ ) to check the band intensity and it was compared with the band intensity of reference $\lambda$ DNA. The quality and concentration of DNA was assessed by a spectrophotometer with the following formula

DNA $(\mu \mathrm{g} / \mu \mathrm{l})=$

$\underline{\mathrm{OD}}_{260} \times 50 \times$ dilution factor $950 \mu \mathrm{l} / \mathrm{ml}$ 1000

\section{Randomly Amplified Polymorphic DNA (RAPD) analysis}

Purified genomic DNA extracts (30-40 ng) from the selected individual were used as template DNA. Commercial kits 'A', 'B', 'C',
' $G$ ' 'H', 'I' and ' $L$ ' of random decamer DNA primers were obtained from Operon Technologies Inc. Alamedas, USA. A total of 24 random decamer DNA primers belonging to above mentioned series were used for RAPD-PCR (Table 2).

One primer at a time was used to study the polymorphism between 16 geographical populations by RAPD assay with genomic DNA extracts from all the 16 geographical populations as template DNA with one control. Master mix required was prepared a fresh together to avoid handling errors. The master mix was distributed to 13 tubes $(23 \mu \mathrm{l}$ per tube) and $2 \mu 1$ of template DNA from the respective location was added to make the total reaction volume to $25 \mu \mathrm{l}$. PCR components including Taq DNA polymerase, dNTPs such as dATP, dGTP, dCTP and dTTP were obtained from M/S. Bangalore Genei Pt. Ltd., Bangalore Eppendorf, Master cycler gradient was used for cyclic amplification of DNA.

The PCR-amplification was done by using following conditions

\begin{tabular}{|l|l|l|l|l|}
\hline Stage & Step & Temperature & Duration (Min) & No. of cycles \\
\hline I. & 1. Initial denaturation & $94^{0} \mathrm{C}$ & 5 & 1 \\
\hline II. & Cycle denaturation & $94^{0} \mathrm{C}$ & 1 & \\
& Annealing & $37^{0} \mathrm{C}$ & 1 & 35 \\
& Extension & $72^{0} \mathrm{C}$ & 2 & \\
\hline III. & 1. Final Extension & $72^{0} \mathrm{C}$ & 8 & 1 \\
& 2. Store & $4^{0} \mathrm{C}$ & - & - \\
\hline
\end{tabular}

After the completion of $\mathrm{PCR}$ reaction the amplified samples were stored at $4^{\circ} \mathrm{C}$ in a refrigerator and the contents were loaded on to 1.0 per cent Agarose gels for electrophoresis separation of amplified products.

Separation of amplified products by Agarose gel electrophoresis

$25 \mu 1$ of the amplified products from each tube mixed with $2 \mu$ l of loading dye were separated on 1 per cent Agarose gel along with $\lambda$ DNA-
EcoR I/Hind III double digest as DNA molecular weight marker and photographed using gel documentation system (Uvitec. Cambridge, England).

\section{Analysis of RAPD profiles}

The amplification profiles for all the primers were compared with each other and the bands of DNA fragments were scored as present (1) or absent (0) generating the 0,1 matrices. 
The genetic similarity was estimated by computing DICE coefficient using NTSYS pc2.0 software programme (Dice, 1945; Nei and $\mathrm{Li}$, 1979). The clustering was done and dendrogram was drawn by following unweighted pair group with arithmetic mean (UPGAM) routine, using the above programme.

\section{Results and Discussion}

RAPD analysis helped characterization of $O$. arenosella populations collected from various parts of Karnataka on the basis of their distinct electrophoretic types permitting closely related individuals, including those from single strike, to be readily distinguished from each other. Analysis of the RAPD data using suitable numerical methods has provided an indication of the genetic homogeneity of $O$. arenosella populations of Karnataka.

Decamer primers belonging to the series OPA, OPG, OPH, OPI, OPL and OPM were initially tested using Channapatna and Kadur populations as templates for optimization of the technique through examining the critical parameters, concentration of primer, magnesium chloride, template DNA and Taq DNA polymerase, as required to obtain reproducible results for the characterization of $O$. arenosella. PCR amplification products were separated by agarose gel electrophoresis. After amplification with each primer only the bright, reproducible bands were scored for data analysis. Twenty four primers (Table 2) provided reproducible polymorphic patterns of amplified DNA fragments and consequently these were used as RAPD markers to resolve genetic polymorphism across the populations collected from different regions of Karnataka. (Plates 1 to 8 are the photographs of the selected gels showing PCR products).

Amplification of genomic DNA across all 16 populations yielded a total of 116 bands. Total number of bands amplified for each of the primer varied between 2 to 10 with an average of 4.83. A lower number of two amplicons were produced by the primers OPA $14\left(5^{1}\right.$ TCTGTGCTGG $\left.\quad 3^{1}\right), \quad$ OPA $\quad 17 \quad\left(5^{1}\right.$ $\begin{array}{lllll}\left.\text { GACCGCTTGT } \quad 3^{1}\right), & \mathrm{H} & 17 & \left(5^{1}\right.\end{array}$ CACTCTCCTC $\left.3^{1}\right)$ and I $16 \quad\left(5^{1}\right.$ TCTCCGCCCT $\left.3^{1}\right)$. The primers $\mathrm{H} 7\left(5^{1}\right.$ $\begin{array}{llllll}\left.\text { CTGCATCGTG } \quad 3^{1}\right) \text { and } & \mathrm{L} & 15 & \left(5^{1}\right.\end{array}$ AAGAGAGGGG $3^{1}$ ) produced a maximum of ten amplicons.

\section{Pooled data}

Assuming equivalence between RAPD markers and other traditional genetic markers, Lynch and Milligan (1994) adopted Nei's genetic distance method to RAPD data. Following the formula of Nei and Li's coefficients of similarity, the genetic distance (similarity coefficient) between populations was estimated based on DNA amplification produced using RAPD primers.

The similarity index for each pair was calculated using arithmetic average (UPGMA) in NTSYS PC2 and presented in table 3. The genetic similarity coefficient based on the frequent band sharing among the populations varied from 0.63 to 0.98 . The lowest genetic similarity was noticed between the farthest populations and highest between the closest populations. All the Karnataka populations had lower genetic similarity values when compared in pairs with Gujarat and Kerala populations. Higher similarity index values were found among the populations within Karnataka.

Pooled data from all the 24 primers revealed the lowest genetic similarity index of 0.63 between Kerala and Gujarat populations followed by 0.68 each between Yellembalase and Gujarat and between Lakshmipura and Gujarat populations. A maximum genetic similarity of 0.98 was recorded among the 
populations of Malpe and Padubidre. This was followed by similarity index of 0.97 between Marase and Lakshmipura populations.

\section{Cluster analysis}

Phylogeography obtained by clustering the 16 populations of $O$. arenosella is provided in Figure 1. Clustering analysis of the $O$. arenosella populations clearly showed that populations existed as two major groups, 'A' and ' $\mathrm{B}$ '. It was observed that all the 16 test populations existed as a unique population till 75 per cent similarity coefficient. After this point, the genetic difference among the populations was noticed. In cluster analysis, the first group ('B') comprised 15 populations while the distinct second group (A) consisted of only Gujarat population, and was separated out from rest of populations at a similarity coefficient of 0.75 . The remaining 15 populations showing similarity coefficient values between 0.8 and 0.98 and formed the second major cluster (cluster B). The ' $\mathrm{B}$ ' group further subdivided into 'B1' and 'B2' at a similarity coefficient of 0.81 , with ' $\mathrm{B} 1$ ' comprising of only two populations from Malleshwara and Channapatna. The 'B2' group comprising 13 geographical populations included two distinct groups (at a similarity coefficient of 0.84).

Kerala population separated from the ' $\mathrm{B}_{2}$ subcluster and formed an independent cluster $\left(B_{2} .1\right)$, while, the rest of the ' $B_{2}$ remained in the same cluster to form ' $\mathrm{B}_{2} .2$ ' cluster. Finally, the ' $\mathrm{B}_{2}$. ' cluster branched into different sub clusters with Nittur, Bhadravathi and Nanjanagud, Malpe and Padubidre, Honnali, Mangalore, Mathighatta and Mandya, Yellambalase, and Marase and Lakshmipura forming eight independent clusters.

The Malpe and Padubidre populations shared a maximum genetic similarity of 98 per cent followed by Marase and Lakshmipura populations, sharing next highest genetic similarity of about 96.5 per cent.

The hypothesis in question was that during outbreaks, when the populations of $O$. arenosella are rapidly spreading, a parent population splits into several new populations. The new population is spatially separated from others and the equilibrium around which generations of the new population cycles is a factor of the nature of the population and its interaction with the local environment, therefore increasing the probability of asynchrony between two sister populations. This would give rise to the observed condition wherein discontinuous populations follow discrete generation cycles that are not in synchrony with other populations. If the above-mentioned hypothesis were true, it was expected that the genetic similarity between populations would decrease with distance.

The overall genetic similarity between populations of $O$. arenosella ranged from 63 to $98 \%$, which may be considered as 'high'. On a broad scale, results obtained agreed with the hypothesis proposed that spatial distance and genetic similarity were inversely related.

Populations of Malpe and Padubidre, which were separated by a 2 KM stretch of uninfested coconut trees and an open land, shared 98 per cent genetic similarity among them. Notably, the two populations mentioned above were asynchronous. Similarly, genetic similarity between populations of Marase and Lakshmipura of Mysore taluk, which were separated by a distance of eight kilometers, was $~ 97$ per cent. As expected, high genetic diversity was noticed among the distant populations, which was evident from the low genetic similarity between populations in Gujarat and populations from the studied locations in Karnataka. Parallel trend was also noticed between populations from Kerala and Karnataka. 
Table.1 The location details of the caterpillars which were sampled / collected for genetic diversity analysis

\begin{tabular}{|l|l|}
\hline Sl. No. & \multicolumn{1}{|c|}{ Name of place } \\
\hline $\mathbf{1}$ & Nittor, Tumakuru district, Karnataka. \\
\hline $\mathbf{2}$ & Bhadravathi, Shivamogga district, Karnataka. \\
\hline $\mathbf{3}$ & Nanjanagud, Mysore district, Karnataka. \\
\hline $\mathbf{4}$ & Malleswara, Kadur taluk, Chaikkamagaluru district, Karnataka. \\
\hline $\mathbf{5}$ & Channapattana, Ramanagara district, Karnataka. \\
\hline $\mathbf{6}$ & Malpe, Udupi district, Karnataka. \\
\hline $\mathbf{7}$ & Padubidre, Udupi district, Karnataka. \\
\hline $\mathbf{8}$ & Honnali, Davanagere district, Karnataka. \\
\hline $\mathbf{9}$ & Mathighatta, Kadur taluk, Chaikkamagaluru district, Karnataka. \\
\hline $\mathbf{1 0}$ & Yellambalase, Kadur taluk, Chaikkamagaluru district, Karnataka. \\
\hline $\mathbf{1 1}$ & Marase, Mysore district, Karnataka. \\
\hline $\mathbf{1 2}$ & Mandya, Mandya district, Karnataka. \\
\hline $\mathbf{1 3}$ & Mangalore town, Karnataka. \\
\hline $\mathbf{1 4}$ & Lakshmipura, Mysore district, Karnataka. \\
\hline $\mathbf{1 5}$ & Navasari, Gujarat. \\
\hline $\mathbf{1 6}$ & Kayangulum, Kerala. \\
\hline
\end{tabular}

Table.2 List of RAPD primers which amplified the genomic DNA

\begin{tabular}{|c|l|l|}
\hline Sl. No. & Primer code & Sequence $\mathbf{5}^{\mathbf{~}} \mathbf{- \mathbf { 3 } ^ { \mathbf { 1 } }}$ \\
\hline $\mathbf{1}$ & OPA -14 & TCTGTGCTGG \\
\hline $\mathbf{2}$ & OPA -16 & AGCCAGCGAA \\
\hline $\mathbf{3}$ & OPA -17 & GACCGCTTGT \\
\hline $\mathbf{4}$ & OPA -18 & AGGTGACCGT \\
\hline $\mathbf{5}$ & OPA -19 & CAAACGTCGG \\
\hline $\mathbf{6}$ & OPA -20 & GTTGCGATCC \\
\hline $\mathbf{7}$ & OPG -4 & AGCGTGTCTG \\
\hline $\mathbf{8}$ & OPG -5 & CTGAGACGGA \\
\hline $\mathbf{9}$ & OPG -7 & GAACCTGCGG \\
\hline $\mathbf{1 0}$ & OPG -8 & TCACGTCCAC \\
\hline $\mathbf{1 1}$ & OPH -6 & ACGCATCGCA \\
\hline $\mathbf{1 2}$ & OPH -7 & CTGCATCGTG \\
\hline $\mathbf{1 3}$ & OPH -9 & TGTAGCTGGG \\
\hline $\mathbf{1 4}$ & OPI -11 & ACATGCCGTA \\
\hline $\mathbf{1 5}$ & OPI -12 & AGAGGGCACA \\
\hline $\mathbf{1 6}$ & OPI -14 & TGACGGCGGT \\
\hline $\mathbf{1 7}$ & OPI -15 & TCATCCGAGG \\
\hline $\mathbf{1 8}$ & OPI -16 & TCTCCGCCCT \\
\hline $\mathbf{1 9}$ & OPL -11 & ACGATGAGCC \\
\hline $\mathbf{2 0}$ & OPL -12 & GGGCGGTACT \\
\hline $\mathbf{2 1}$ & OPL -13 & ACCGCCTGCT \\
\hline $\mathbf{2 2}$ & OPL -14 & GTGACAGGCT \\
\hline $\mathbf{2 3}$ & OPL -15 & AAGAGAGGGG \\
\hline $\mathbf{2 4}$ & OPM $-\mathbf{8}$ & GGGAACGTGT \\
\hline & & \\
\hline
\end{tabular}


Table.3 Matrix of genetic similarity indices for different populations of $O$. arenosella

\begin{tabular}{|c|c|c|c|c|c|c|c|c|c|c|c|c|c|c|c|c|}
\hline 氕 & $\begin{array}{l}\frac{\pi}{\pi} \\
\text { ⿹勹巳 }\end{array}$ & 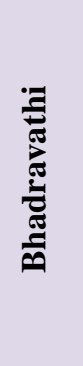 & 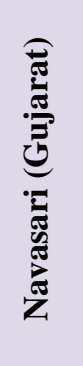 & 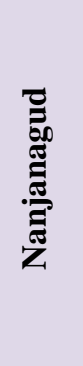 & 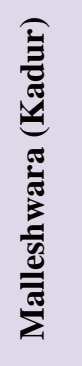 & 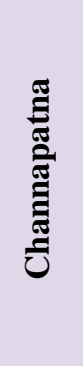 & $\frac{\Xi}{\bar{\Xi}}$ & 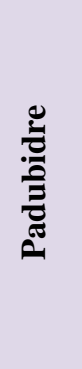 & 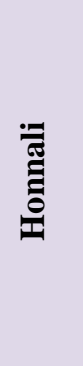 & 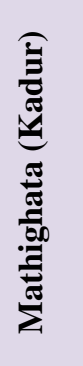 & 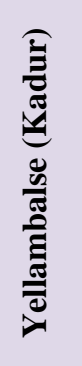 & 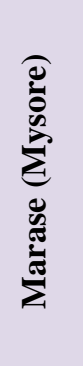 & 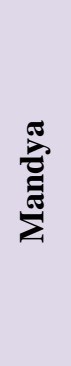 & 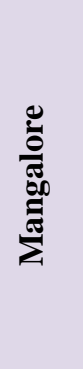 & 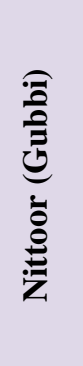 & 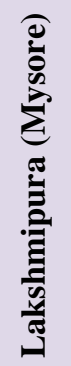 \\
\hline $\begin{array}{l}\text { Kayangulum } \\
\text { (Kerala) }\end{array}$ & 1.00 & & & & & & & & & & & & & & & \\
\hline Bhadravathi & 0.87 & 1.00 & & & & & & & & & & & & & & \\
\hline $\begin{array}{l}\text { Navasari } \\
\text { (Gujarat) }\end{array}$ & 0.63 & 0.76 & 1.00 & & & & & & & & & & & & & \\
\hline Nanjanagud & 0.89 & 0.95 & 0.80 & 1.00 & & & & & & & & & & & & \\
\hline $\begin{array}{l}\text { Malleshwara } \\
\text { (Kadur) }\end{array}$ & 0.70 & 0.89 & 0.82 & 0.79 & 1.00 & & & & & & & & & & & \\
\hline Channapatna & 0.70 & 0.89 & 0.77 & 0.82 & 0.87 & 1.00 & & & & & & & & & & \\
\hline Malpe & 0.87 & 0.95 & 0.82 & 0.97 & 0.94 & 0.90 & 1.00 & & & & & & & & & \\
\hline Padubidre & 0.85 & 0.93 & 0.80 & 0.91 & 0.86 & 0.79 & 0.98 & 1.00 & & & & & & & & \\
\hline Honnali & 0.89 & 0.93 & 0.77 & 0.92 & 0.83 & 0.83 & 0.93 & 0.93 & 1.00 & & & & & & & \\
\hline $\begin{array}{l}\text { Mathighata } \\
\text { (Kadur) }\end{array}$ & 0.79 & 0.86 & 0.75 & 0.90 & 0.87 & 0.77 & 0.90 & 0.83 & 0.83 & 1.00 & & & & & & \\
\hline $\begin{array}{l}\text { Yellambalse } \\
\text { (Kadur) }\end{array}$ & 0.84 & 0.92 & 0.68 & 0.88 & 0.88 & 0.83 & 0.96 & 0.88 & 0.91 & 0.92 & 1.00 & & & & & \\
\hline $\begin{array}{l}\text { Marase } \\
\text { (Mysore) }\end{array}$ & 0.86 & 0.85 & 0.70 & 0.85 & 0.72 & 0.69 & 0.94 & 0.90 & 0.89 & 0.76 & 0.86 & 1.00 & & & & \\
\hline Mandya & 0.83 & 0.91 & 0.78 & 0.95 & 0.83 & 0.85 & 0.92 & 0.90 & 0.89 & 0.93 & 0.91 & 0.83 & \#\#\# & & & \\
\hline Mangalore & 0.82 & 0.89 & 0.72 & 0.91 & 0.76 & 0.80 & 0.92 & 0.95 & 0.91 & 0.88 & 0.86 & 0.84 & \#\#\# & 1.00 & & \\
\hline Nittur (Gubbi) & 0.80 & 0.84 & 0.77 & 0.86 & 0.75 & 0.71 & 0.87 & 0.89 & 0.84 & 0.80 & 0.80 & 0.86 & \#\#\# & 0.77 & 1.00 & \\
\hline $\begin{array}{l}\text { Lakshmipura } \\
\text { (Mysore) }\end{array}$ & 0.83 & 0.84 & 0.68 & 0.85 & 0.78 & 0.75 & 0.94 & 0.93 & 0.87 & 0.80 & 0.87 & 0.97 & \#\#\# & 0.88 & 0.82 & 1.00 \\
\hline
\end{tabular}


Plate.1 RAPD profiles of the primer OPG -04

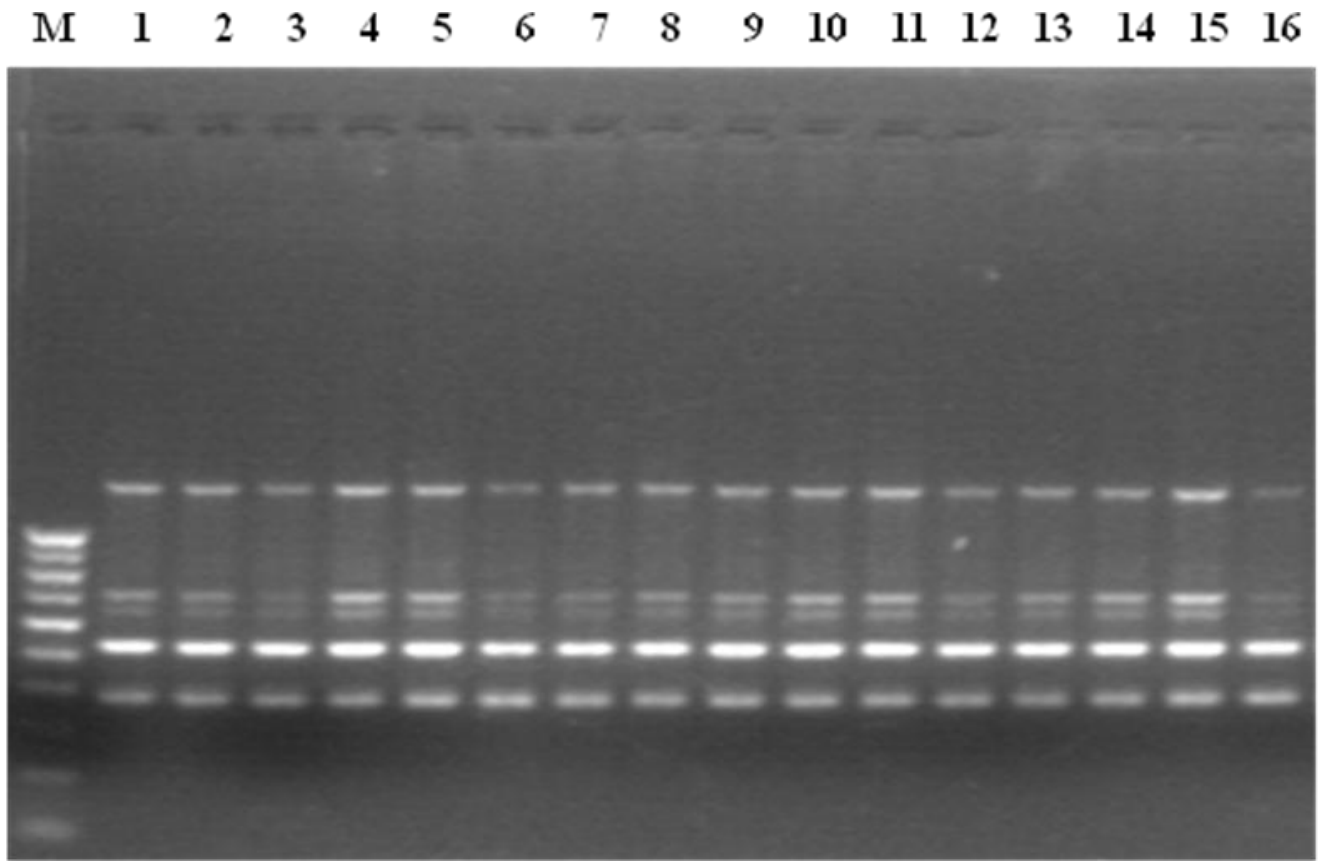

Plate.2 RAPD profiles of the primer OPG - 05

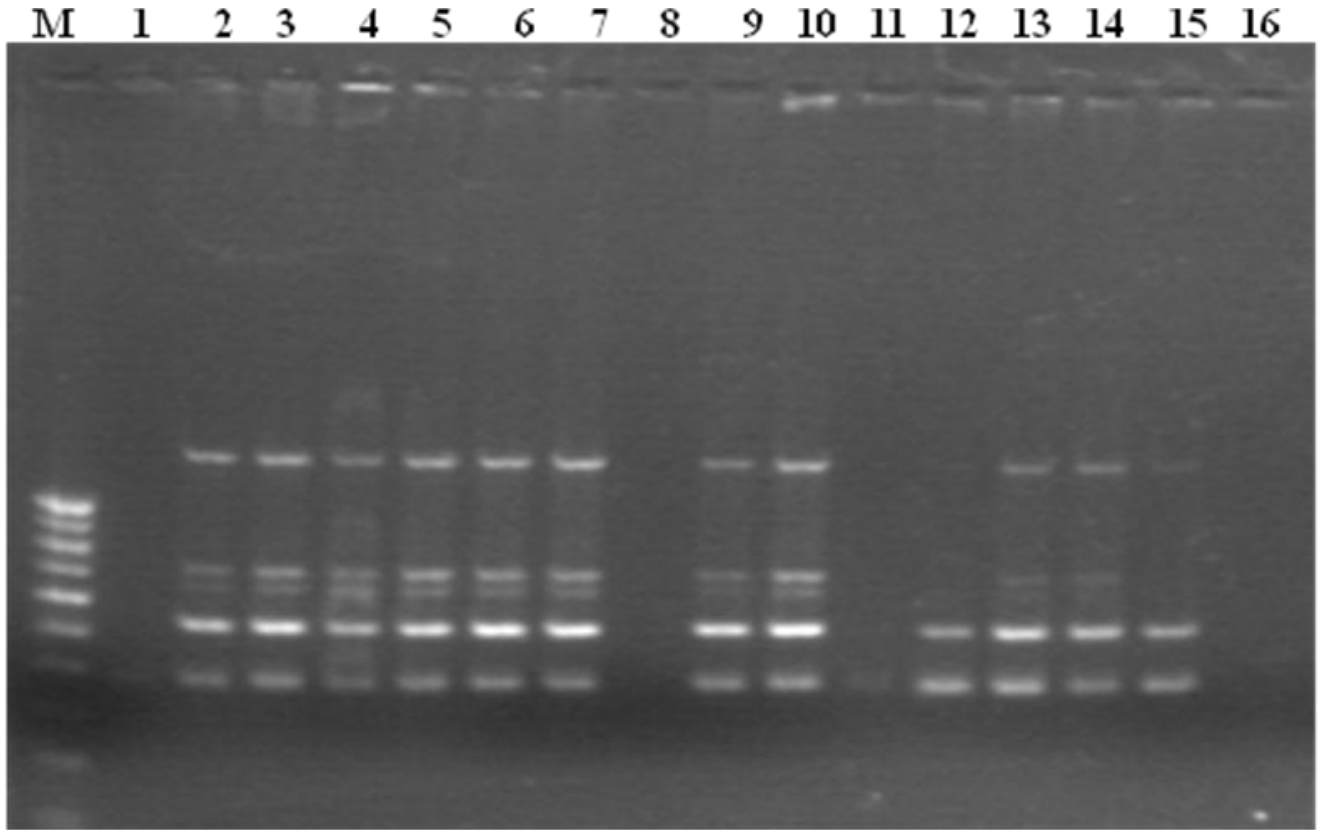

L-M: Marker:L-1: Nittor, L-2: Bhadravathi, L-3:Navsari (Gujarat), L-4:Nanjanagudu, L-5: Malleshwara (Kadur), L6: Channapatna,L-7: Malpe, L-8: Padubidre, L-9: Honnali, L-10: Mathighatta (Kadur), L-11: Yellambalase (Kadur), L-12: Marase (Mysore, L-13: Mandya, L-14: Mangalore, L-15: Kayangulum (Kerala), L-16: Lakshmipura (Mysore) 
Int.J.Curr.Microbiol.App.Sci (2019) 8(1): 1760-1772

Plate.3 RAPD profiles of the primer OPG - 07

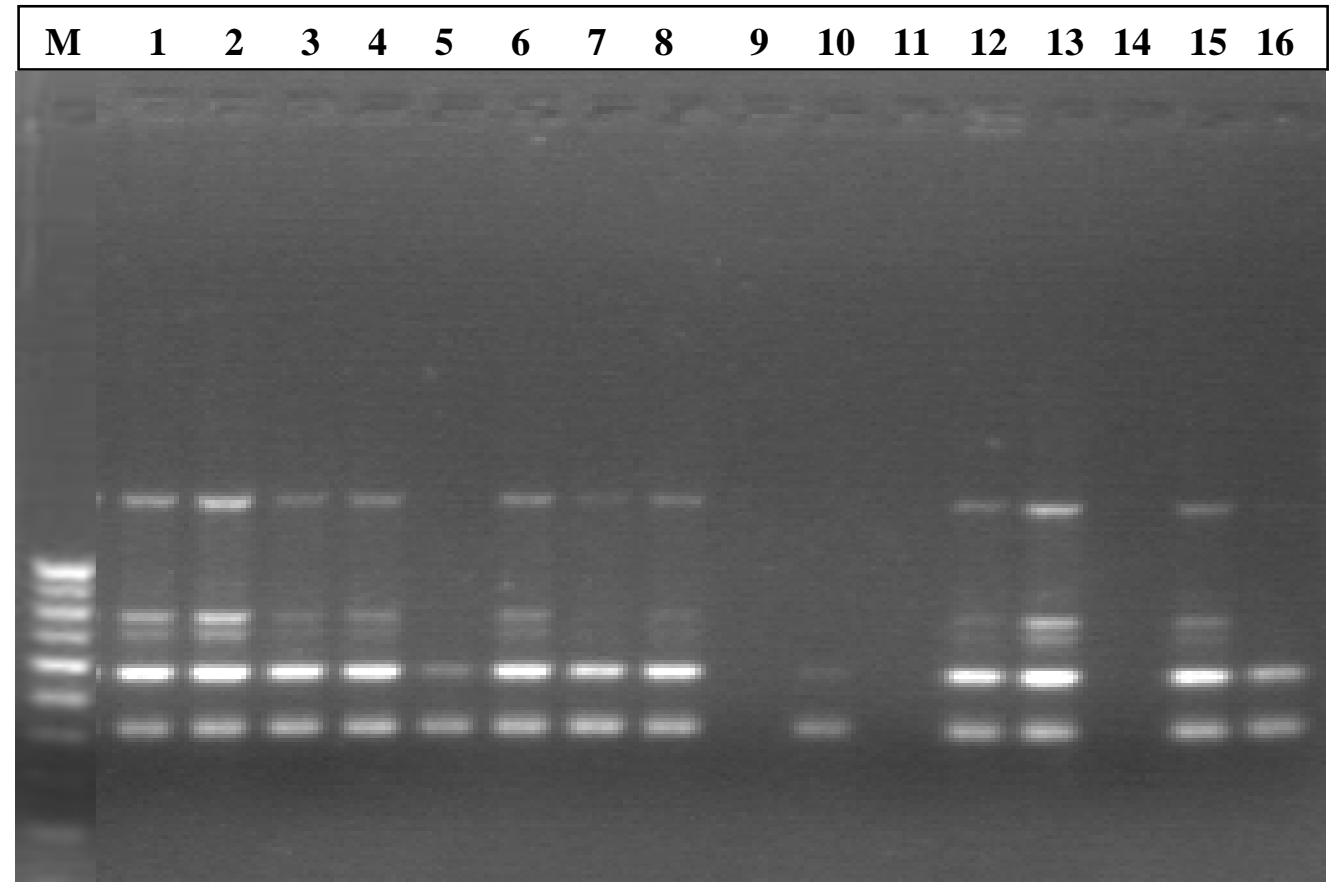

Plate.4 RAPD profiles of the primer OPG - 08

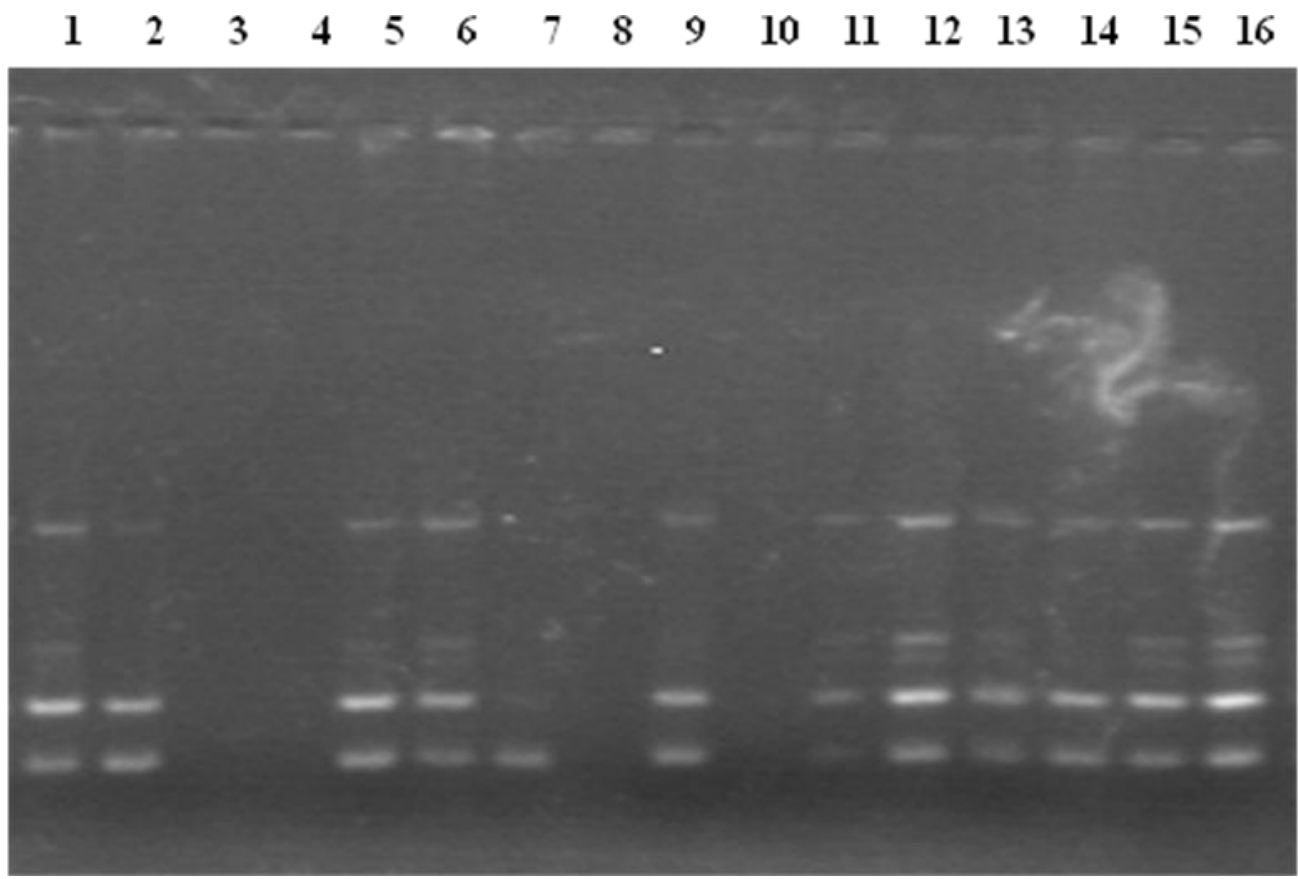

L-M: Marker:L-1: Nittor, L-2: Bhadravathi, L-3:Navsari (Gujarat), L-4:Nanjanagudu, L-5: Malleshwara (Kadur), L6: Channapatna,L-7: Malpe, L-8: Padubidre, L-9: Honnali, L-10: Mathighatta (Kadur), L-11: Yellambalase (Kadur), L-12: Marase (Mysore, L-13: Mandya, L-14: Mangalore, L-15: Kayangulum (Kerala), L-16: Lakshmipura (Mysore) 
Plate.5 RAPD profiles of the primer OPH -06

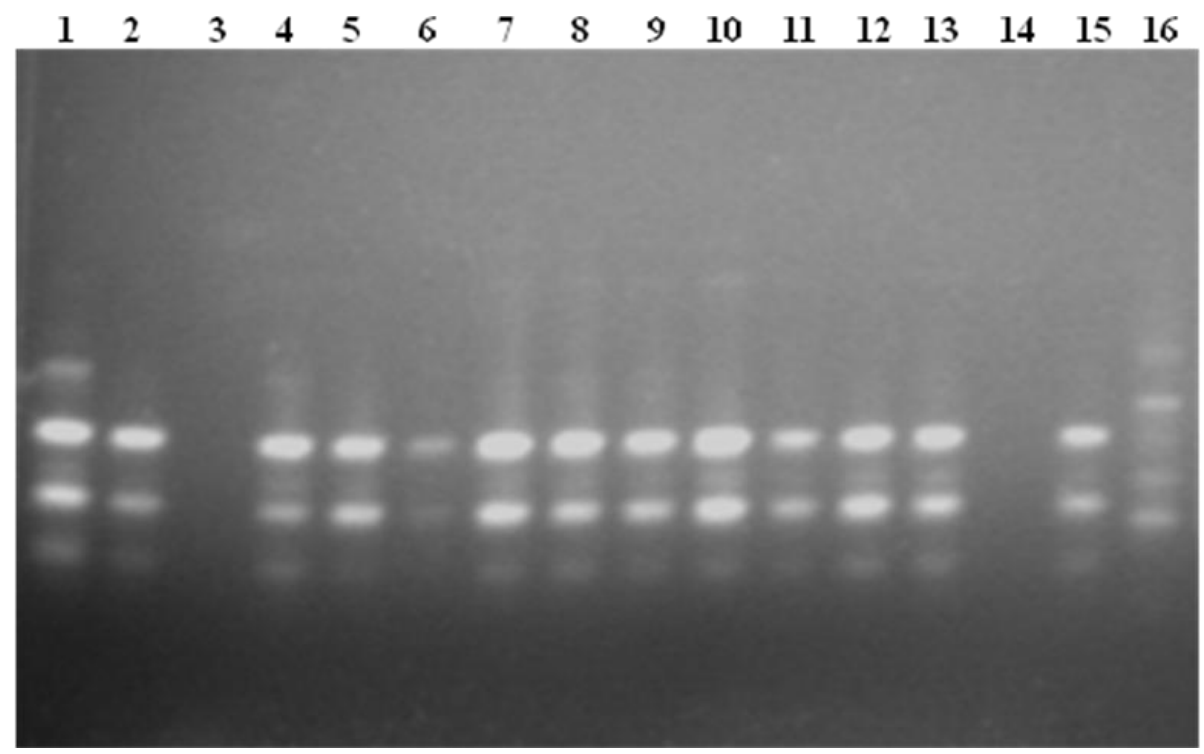

Plate.6 RAPD profiles of the primer OPH - 08

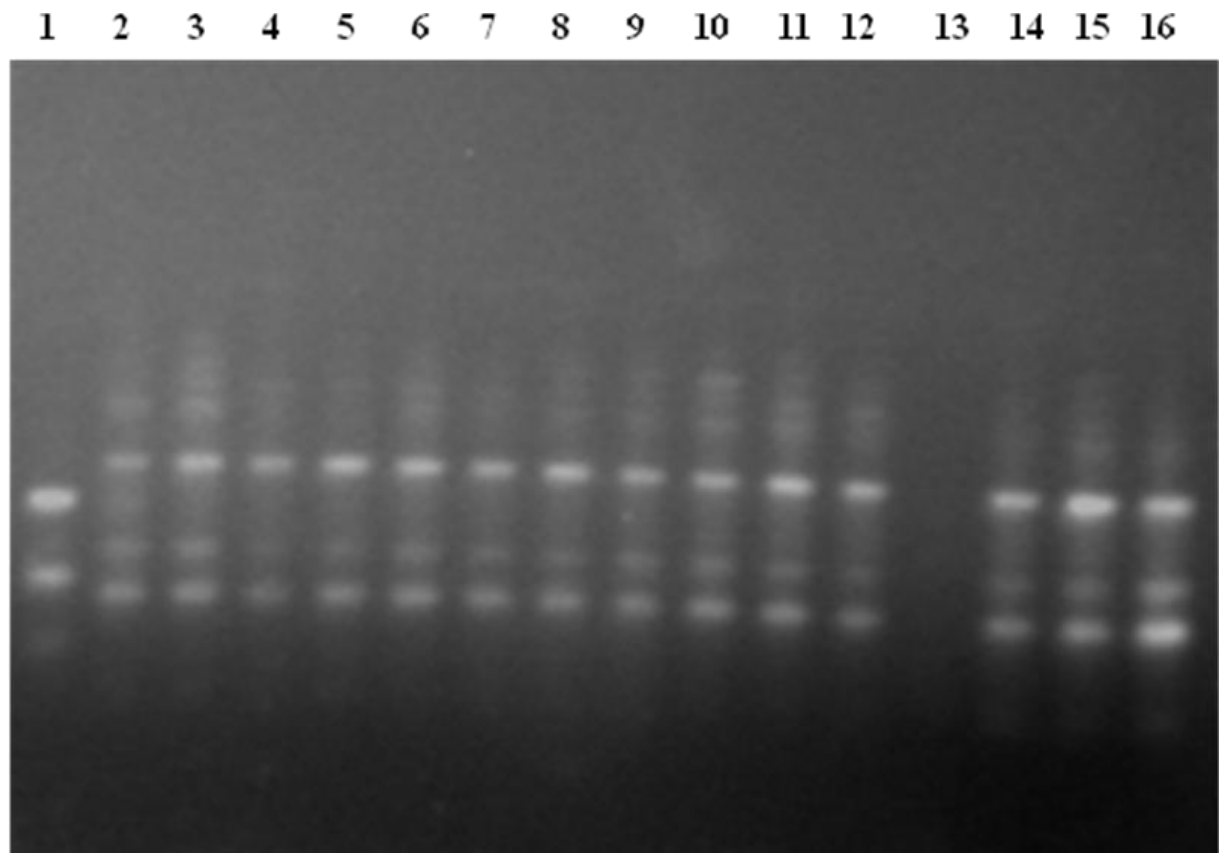

L-M: Marker:L-1: Nittor, L-2: Bhadravathi, L-3:Navsari (Gujarat), L-4:Nanjanagudu, L-5: Malleshwara (Kadur), L6: Channapatna,L-7: Malpe, L-8: Padubidre, L-9: Honnali, L-10: Mathighatta (Kadur), L-11: Yellambalase (Kadur), L-12: Marase (Mysore, L-13: Mandya, L-14: Mangalore, L-15: Kayangulum (Kerala), L-16: Lakshmipura (Mysore) 
Int.J.Curr.Microbiol.App.Sci (2019) 8(1): 1760-1772

Plate.7 RAPD profiles of the primer OPL -15

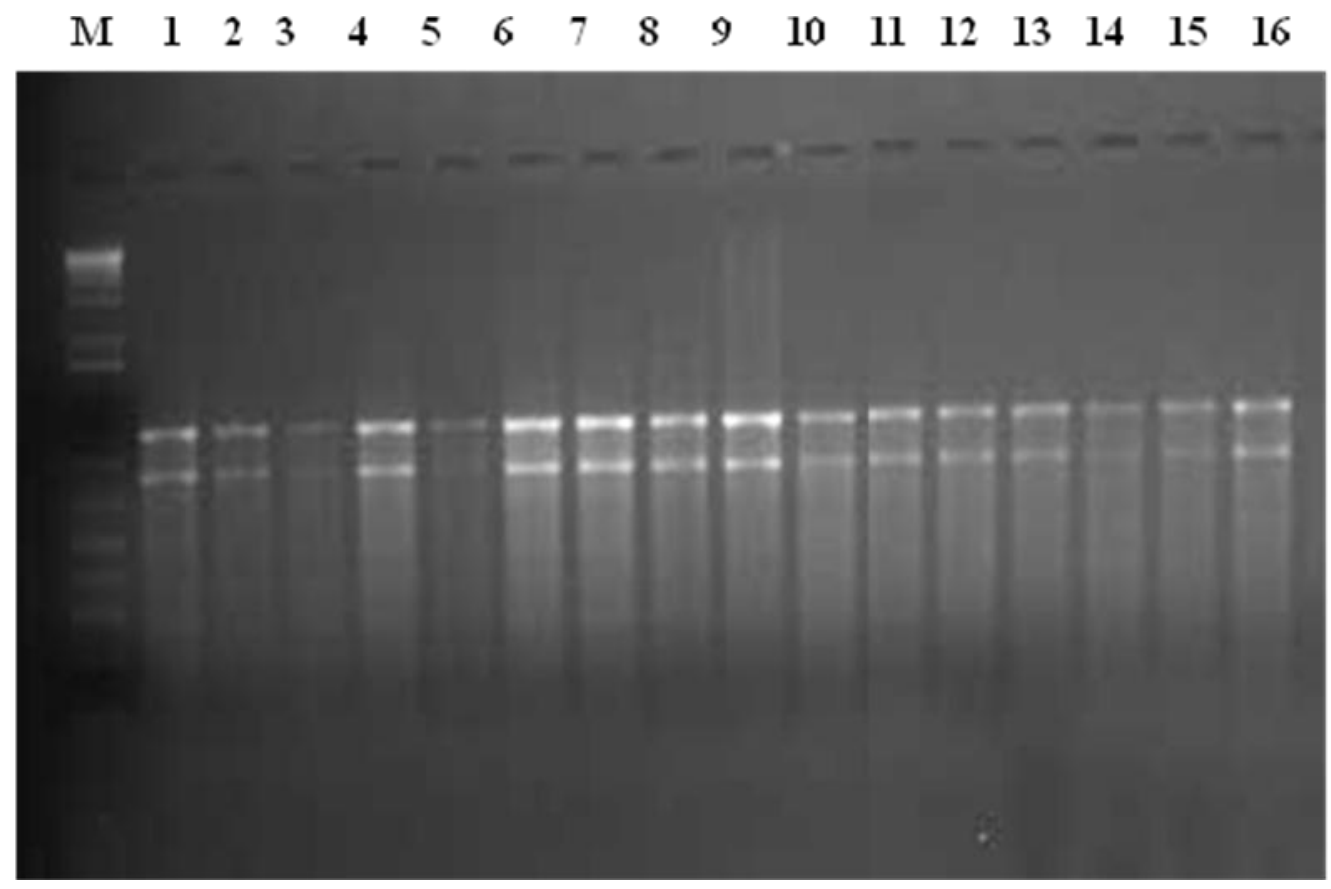

Plate.8 RAPD profiles of the primer OPA - 14

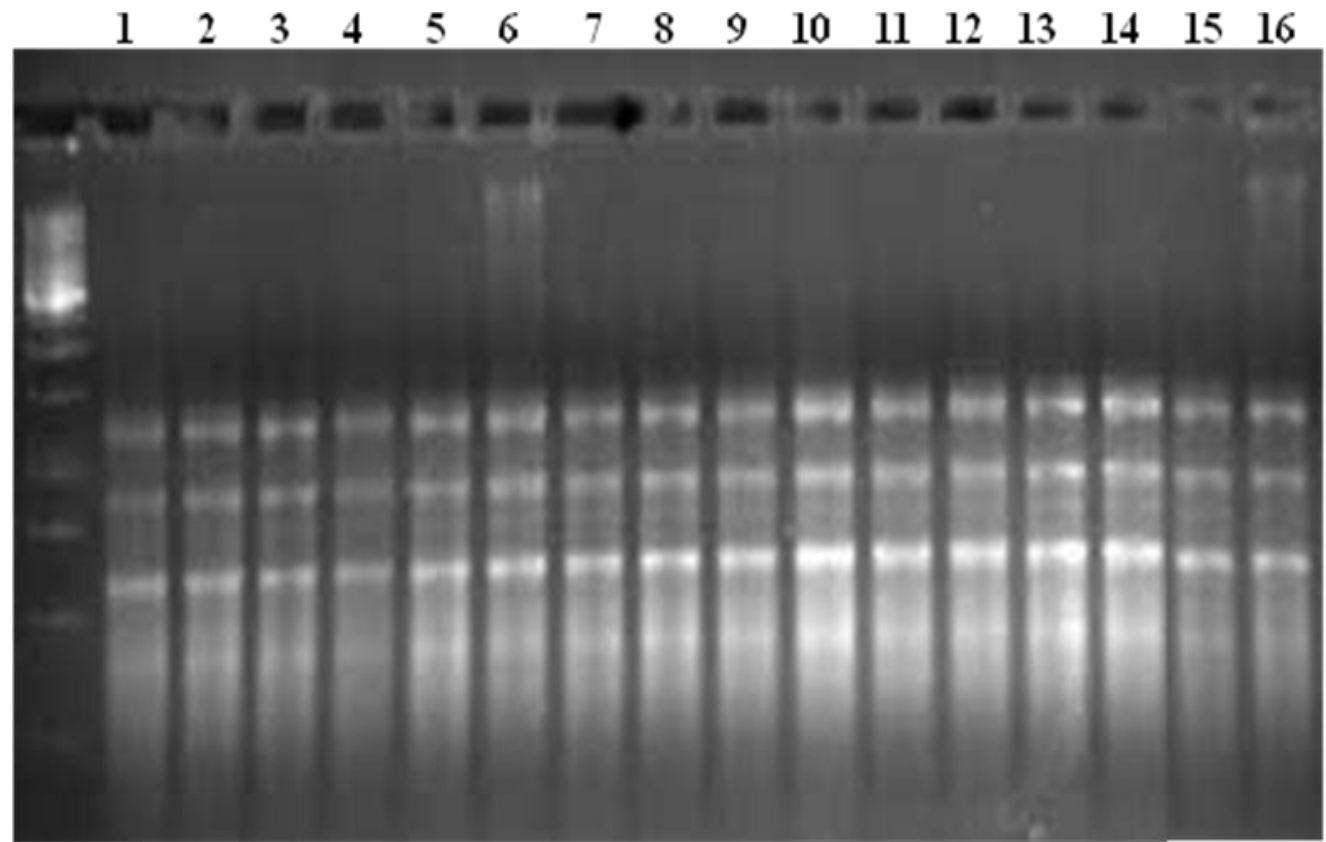

L-M: Marker:L-1: Nittor, L-2: Bhadravathi, L-3:Navsari (Gujarat), L-4:Nanjanagudu, L-5: Malleshwara (Kadur), L6: Channapatna,L-7: Malpe, L-8: Padubidre, L-9: Honnali, L-10: Mathighatta (Kadur), L-11: Yellambalase (Kadur), L-12: Marase (Mysore, L-13: Mandya, L-14: Mangalore, L-15: Kayangulum (Kerala), L-16: Lakshmipura (Mysore). 
Interestingly, comparisons within populations of Karnataka also show that certain populations that were spatially close were less similar than the ones that were farther off. Such situations are possible only when populations originating from the same parent population get isolated to far away locations during population shrinkage, and when populations originating from different parent populations may shrink to spatially nearer locations. Therefore, there are reasons to believe that the hypothesis proposed may be true.

Akin to the genetic diversity of $O$. arenosella, Borges et al., (2000) observed a correlation between genetic and geographical distances for the populations of Triatoma brasiliensis, a vector of human chagas disease using RAPD analysis. Evidences contrary to the above can be drawn from rice yellow stem borer, where the genetic diversity among geographically separated populations across India is independent of distance (Kumar et al., 2001). Overall, high genetic similarity between the populations of $O$. arenosella suggests 1) populations arise from a common nucleus population, 2) populations inbreed and 3) immigration/emigration is practically zero. Corroborating with the argument, the polyphagous and migratory species like Helicoverpa armigera is reported to have a higher levels of genetic variability among the populations within and between locations (Fakrudin et al., 2004). However, as each population follows discrete generation cycles that may or may not be temporally synchronized, there must be no situation when two populations get mixed. This can be possible only when the migrating moths avoid oviposition in freshly infested gardens.

\section{References}

Apostol, B. L., Black, W. C., IV, Reiter, P. and Miller, B. R., 1996. Population genetics with RAPD-PCR marker: The breeding structure of Aedes aegypti in Puerto Rico. Heredity, 76(4): 325-328

Block, V. C., Phillips, M. S. and Harrower, B. E., 199. Comparison of British populations of potato cyst nematodes with populations from continental Europe and South America using RAPDs. Genome, 40: 286-289

Borges, E. C., Dujardin, J. P., Schofield, C. J., Romanha, A. J. and Diotaiuti, L., 2000. Genetic variability of Triatoma brasiliensis (Hemiptera: Reduviidae) populations. J. Med. Entomol., 37: 872877

Cenis, J. L., 1993. Identification of four major Meloidogyne spp. by random amplified polymorphic DNA (RAPD-PCR). Phytopathology, 83(1): 76-85

Fakrudin, B., Patil, B. V., Vijaykumar, Krishnareddy, B. K., Prakash, S. H. and Kuruvinashetti, M. S., Genetic structure of cotton bollworm (Helicoverpa armigera Hubner) populations occurring in South Indian cotton ecosystems using RAPD markers. International Symposium on Strategies for Sustainable Cotton Production - A Global Vision 3. Crop Protection, 23-25 November 2004, University of Agricultural Sciences, Dharwad, Karnataka (India)

Hartl, D. L., 1980. Principles of Population Genetics, Sinauer Associates Inc., Sunderland, MA.

Haymer, D. S., 1994. Arbitrary (RAPD) primer sequences used in insect studies. Insect Mol. Biol., 3(3): 191-196

Kambhampati, S., Black, N. C., Rai, K. S. and Sprenger, D., 1990. Temporal variation in genetic structure of a colonizing species, Aedes albopictus in the United States. Heredity, 64: 281-287

Kumar, L. S., Sawant, A. S., Gupta, V. S. and Ranjekar, P. K., 2001. Genetic variation in Indian populations of Scirpophaga 
incertulas as revealed by RAPD-PCR analysis, Biochem. Genet., 39(1/2): 4357

Loxadale, H. D., Brookes, C. P. and De Barro, P. J., 1996. Analysis of Heterodera anenae population by the randomly amplified polymorphic DNA technique. Genome, 39:118

Maniatis, T., Fritsch, E. F. and Sambrook, J., 1982. Molecular cloning; A laboratory manual, Cold Spring Harbour Laboratory, Cold Spring Harbour, USA

Murray, M. G. and Thompson, W. F, 1980. Rapid isolation of high molecular weight plant DNA. Nucleic Acids Res., 8:4321-4325

Ramkumar, K. Muralimohan, L. Kiranmayi and Y. B. Srinivasa, 2006. Discrete generation cycles in the tropical moth Opisina arenosella. Current Science 91: 811-816
Silveria, E. B., Al-Janabi, S. M., Magalhaes, B. P., Carvalho, L. J. C.B. and Tigano, M. S., 1998. Polymorphism of the grasshopper Schistocerca pallens (Thunberg) (Orthoptera: Acrididae) and its natural pathogen Metarhizium flavoviridae Gams and Rozsypal (Hyphomycetes) revealed by RAPD analysis. Ann. Entomol. Soc. Brazil, 27(1): 91-96

Templeton, A. R., Shaw, K., Routman, E and Davis, S. K., 1990. The genetic consequences of habitat fragmentation. Ann. Missouri. Bot. Gard., 77: 13-27

Williams, C. L., Goldson, S. L., Baird, D. B. and Bullock, D. W., 1994. Geographical origin of an introduced insect pest, Listronotus bonariensis (Kuschel), determined by RAPD analysis. Heredity, 72: 412-419

\section{How to cite this article:}

Muralimohan, K., B. Shivanna and Nagesha, N. 2019. Genetic Diversity of Spatially Isolated Populations of Coconut Caterpillar, Opisina arenosella (Oecophoridae: Lepidoptera). Int.J.Curr.Microbiol.App.Sci. 8(01): 1760-1772. doi: https://doi.org/10.20546/ijcmas.2019.801.187 